\title{
Vitalnost šumskoga drveća na bioindikacijskoj plohi u Nacionalnom parku Plitvička jezera
}

\author{
Damir Ugarković, Ana Hodak, Ivica Tikvić, Krešimir Popić
}

\begin{abstract}
Nacrtak-Abstract
Osutost krošanja stabala jedan je od indikatora vitalnosti šumskoga drveća. Cilj je istraživanja bio analizirati osutost krošanja stabala obične jele i obične smreka s bioindikacijske plohe $u$ Nacionalnom parku Plitvička jezera. Iz Upisnika Razine 1 Nacionalnoga programa motrenja oštećenosti šumskih ekosustava prikupljeni su podaci o osutosti krošanja stabala obične jele $i$ obične smreke s bioindikacijske plohe u Nacionalnom parku Plitvička jezera. Vrijednosti samokalibriranoga Palmerova indeksa oštrine suhoće (scPDSI) prikupljene su s mrežne aplikacije KNMI Climate Explorer. S obzirom na osutost krošanja i mortalitet stabala obična jela i obična smreka dobre su vitalnosti na bioindikacijskoj plohi. Suša je utjecala na značajnu osutost krošanja stabala obične smreke, dok kod obične jele to nije bio slučaj. Potrebno je nastaviti promatranje vitalnosti šumskoga drveća te povećati broj ploha s motrenjem osutosti krošanja stabala, klime $i$ ostalih ekoloških čimbenika u Nacionalnom parku.
\end{abstract}

Ključne riječi: osutost krošanja, obična jela, obična smreka, Nacionalni park Plitvička jezera

\section{Uvod - Introduction}

Sustavnim praćenjem i motrenjem (monitoringom) stanja ekoloških čimbenika i šumskih ekosustava pridonosimo stabilnosti i očuvanju šumskih ekosustava, odnosno utvrđivanju uzroka i promjena u ekosustavima. Općenito u svijetu postoji dosta istraživačkih programa i monitoringa, a jedan od njih je i Međunarodni program za praćenje i motrenje utjecaja zračnoga onečišćenja na šume u Europi (ICP Forests) (Potočić i Seletković 2011). Koja su područja zanimljiva za uspostavu monitoringa, svakako ovisi o objektu istraživanja. To su područja s velikim antropogenim utjecajem i bez njega te područja u kojima je u prošlosti bio organiziran manji ekološki monitoring, a cilj nam je doznati događaju li se negativne promjene, ponajprije je li stanište degradirano (Spellerberg 2005). Monitoring stanja krošanja šumskih vrsta drveća u Republici Hrvatskoj, koji se od 1987. godine provodi u sklopu Međunarodnoga programa za procjenu i motrenje utjecaja zračnoga onečišćenja na šume, najdugovječniji je monitoring u šumskim ekosustavima. Motrenje se stanja kroša- nja obavlja prema ICP Forests priručniku (Eichorn i dr. 2016) i Pravilniku o načinu motrenja oštećenosti šumskih ekosustava (NN 54/2019). Jedan od pokazatelja vitalnosti stabala i šumskih ekosustava jest i osutost krošanja stabala (Tikvić i dr. 2011). Ona je ujedno i jedan od pokazatelja stanja stresa kod stabala, a javlja se kao manjak iglica ili lišća u postotnom iznosu u odnosu na referentno stanje krošnje. Osutost se krošanja može mijenjati iz godine u godinu i naglo porasti zbog jakoga stresa, primjerice suše. Stabla se mogu oporaviti od gubitka lišća, pri čemu razdoblje povratka na vrijednosti prije stresa ovise o vrsti šumskoga drveća te o okolišnim uvjetima. Stoga ne možemo povezivati svaki porast osutosti s trajnim smanjenjem vitalnosti stabala.

Prema Gruberu (1994) najrašireniji simptom šteta u Europi na običnoj jeli i običnoj smreci jest osutost krošanja stabala. Povećanjem osutosti krošanja stabala povećava se odumiranje stabala (Dobertin i Brang 2001), a ono je povezano s kompleksom promjenjivoga djelovanja abiotskih i biotskih čimbenika (Ugarković i dr. 2011). S obzirom na to da su šumski ekosustavi jedan od temeljnih fenomena Nacional- 
noga parka Plitvička jezera, donosimo rezultate toga motrenja. Budući da unutar granica parka nema dodatnih ploha s monitoringom stanja krošanja glavnih vrsta šumskoga drveća, u raspravi o rezultatima prikazat ćemo stanje i trendove osutosti obične jele, obične smreke i obične bukve u Lici (regionalna razina), u Republici Hrvatskoj te na europskoj razini.

\section{Materijal i metode rada Material and methods}

Iz Upisnika Razine 1 Nacionalnoga programa motrenja oštećenosti šumskih ekosustava, koji se nalazi pri Hrvatskom šumarskom institutu u Jastrebarskom (Nacionalni koordinacijski centar), prikupljeni su podaci o osutosti krošanja stabala obične jele i obične smreke s bioindikacijske plohe broj 42 . Ploha se nalazi u Nacionalnom parku Plitvička jezera. Na bioindikacijskoj su plohi ukupno 24 stabla obične jele i obične smreke. Riječ je o relativno mlađoj skupini stabala jer su sva stabla prsnih promjera d1 $30 \mathrm{~cm}$ I. debljinskoga razreda $(10-30 \mathrm{~cm})$ i II. debljinskoga razreda $(30-50 \mathrm{~cm})$. Osutost je krošanja procjenjivana u srpnju i kolovozu, a procjenjuje se $\mathrm{u}$ postotku s točnošću od $5 \%$ na predominantnim, dominantnim i kodominantnim stablima Kraftove klasifikacije i svrstava po stupnjevima osutosti (Eichorn i dr. 2016). Podaci se odnose na razdoblje od 1999. do 2017. godine. Podaci o osutosti krošanja odnosno usporedba postotka stabala pojedine vrste šumskoga drveća po stupnjevima osutosti krošanja obavljena je Kruskal-Wallisovim testom. Spearmanovim koeficijentom korelacije analiziran je odnos udjela između stabala obične jele i smreke po stupnjevima osutosti krošanja. Utjecaj suše na pojavu stabala sa značajnom osutosti krošanja, odnosno osutosti krošanja većom od $25 \%$ analiziran je logističkom regresijom. Sušne su godine određene na osnovi vrijednosti Palmerova indeksa oštrine suhoće (Alley 1984). Vrijednosti samokalibriranoga Palmerova indeksa oštrine suhoće (Wells i dr. 2004) prikupljene su iz baze podataka KNMI Climate Explorer. KNMI Climate Explorer je mrežna aplikacija za statističku analizu klimatskih podataka i dio je regionalnoga klimatskoga centra WMO (Svjetske meteorološke organizacije). Svi su podaci obrađeni u programu Statistica 13.3 (TIBCO Software Inc., 2018) uz razinu značajnosti 0,05 .

\section{Rezultati istraživanja s raspravom Results and discussion}

Na slici 1 prikazana je dinamika osutosti krošanja stabala obične jele u razdoblju od 1999. do 2017. godine. Od 2010. godine najveći je postotak stabala imao stupanj osutosti 0 , odnosno nije bilo osutosti krošanja. Tijekom toga razdoblja, 2013. i 2014. godine, nije bilo osutih stabala obične jele. S obzirom na početnu godinu motrenja, na 1999. godinu, možemo reći da se vitalnost stabala obične jele popravila. Mrtvih stabala obične jele (stupanj 4) bilo je $8 \%$ u 2012. godini, što može biti posljedica sušne 2011. godine. Suša ima utjecaj na vitalnost obične jele jer je ona vrsta uske ekološke valencije s obzirom na njezine zahtjeve prema vodi i toplini (Prpić i Seletković 2001). O utjecaju sušnih godina na osutost krošanja stabala obične jele pišu Potočić i Seletković (2013) te zaključuju kako je običnoj jeli potrebno nekoliko godina za oporavak nakon sušnoga razdoblja.

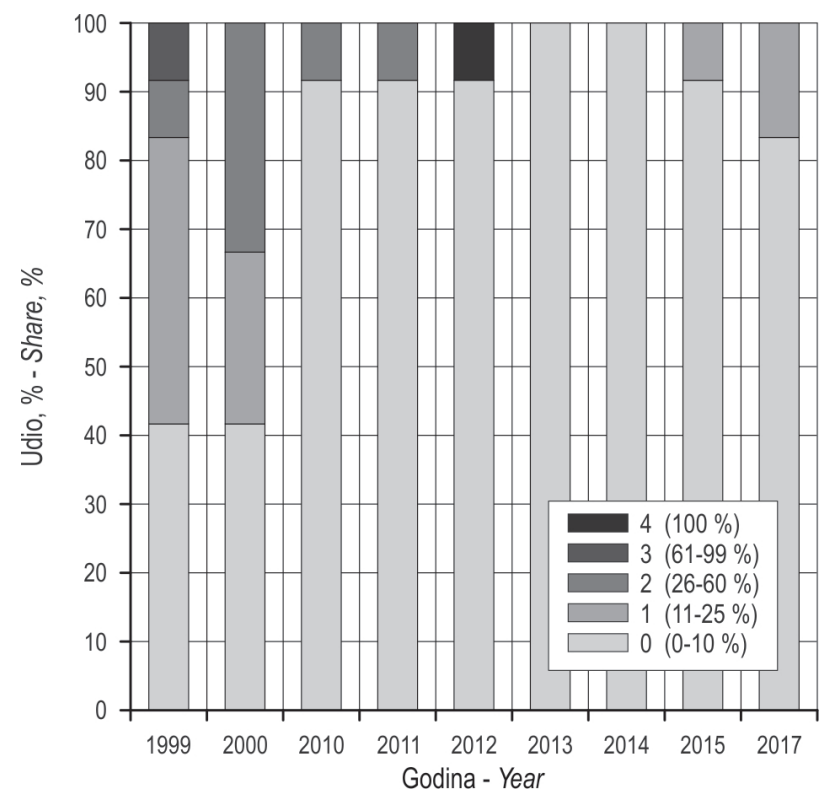

Slika 1. Postotak stabala obične jele po stupnjevima osutosti krošanja u NP Plitvička jezera od 1999. do 2017. godine

Fig. 1 Percentage of silver fir trees by crown defoliation classes in Plitvice Lakes National Park from 1999 to 2017

Na slici 2 prikazana je dinamika osutosti krošanja stabala obične smreke po stupnjevima osutosti. Tijekom motrenja nisu zabilježena stabla čija je osutost krošanja veća od $61 \%$. Od 2010. godine najviše je stabala obične smreke imalo stupanj osutosti 0 , odnosno bilo je bez osutosti krošanja stabala. Prema podacima s bioindikacijske plohe obična je smreka bila dobre vitalnosti. Na bioindikacijskoj plohi nisu zabilježena mrtva stabla obične smreke, što ide $u$ prilog činjenici da je obična smreka vrsta nešto šire ekološke valencije $u$ odnosu na običnu jelu (Prpić i Seletković 2001). Obična je smreka dobre vitalnosti 
i drugdje u Europi. Prema izvješću o stanju šuma u Europi (Michel i dr. 2018) prosječna osutost krošanja stabala obične smreke od 1998. godine do 2017. godine iznosila je oko $20 \%$.

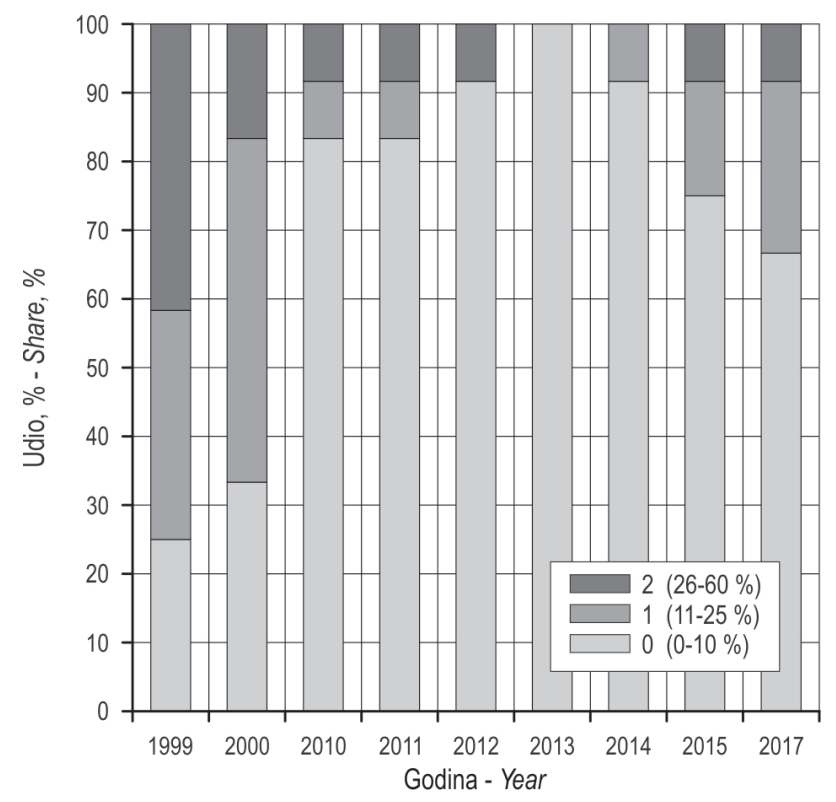

Slika 2. Postotak stabala obične smreke po stupnjevima osutosti krošanja u NP Plitvička jezera od 1999. do 2017. godine

Fig. 2 Percentage of common spruce trees by crown defoliation classes in Plitvice Lakes National Park from 1999 to 2017

Tablica 1. Raspon postotka stabala obične jele i obične smreke (\%) po stupnjevima osutosti od 1999. do 2017. godine

Table 1 Percentage range of silver fir and common spruce trees (\%) by classes and degrees of defoliation for the period 19992017

\begin{tabular}{|l|c|c|}
\hline \multicolumn{1}{|c|}{$\begin{array}{c}\text { Stupanj osutosti } \\
\text { Classes/Degrees }\end{array}$} & $\begin{array}{c}\text { Obična jela } \\
\text { Silver fir }\end{array}$ & $\begin{array}{c}\text { Obična smreka } \\
\text { Common spruce }\end{array}$ \\
\cline { 2 - 3 } & \multicolumn{2}{|c|}{ min. - maks., \% } \\
\hline $\begin{array}{l}\text { 0. Bez osutosti } \\
\text { 0 No defoliation }\end{array}$ & $42-100$ & $25-100$ \\
\hline $\begin{array}{l}\text { 1. Mala osutost } \\
\text { 1 Small defoliation }\end{array}$ & $0-42$ & $0-50$ \\
\hline $\begin{array}{l}\text { 2. Značajna osutost } \\
\text { 2 Moderate }\end{array}$ & $0-33$ & $0-42$ \\
\hline $\begin{array}{l}\text { 3. Velika osutost } \\
\text { 3 Severe }\end{array}$ & $0-8$ & - \\
\hline $\begin{array}{l}\text { 4. Mrtvo stablo } \\
\text { 4 Dead tree }\end{array}$ & $0-8$ & - \\
\hline
\end{tabular}

U tablici 1 prikazan je najmanji i najveći postotak stabala obične jele i obične smreke po stupnjevima osutosti od 1999. do 2017. godine. Najveći postotak stabala obične jele bio je bez osutosti krošanja (100
$\%)$, zatim s malom osutosti krošanja (42 \%) i značajnom osutosti krošanja (33 \%). Najveći je postotak stabala obične smreke bio bez osutosti krošanja (100 $\%)$, zatim s malom osutosti krošanja ( $50 \%$ i značajnom osutosti krošanja (42 \%). Nisu evidentirana stabla obične smreke s velikom osutosti i mrtva stabla obične smreke.

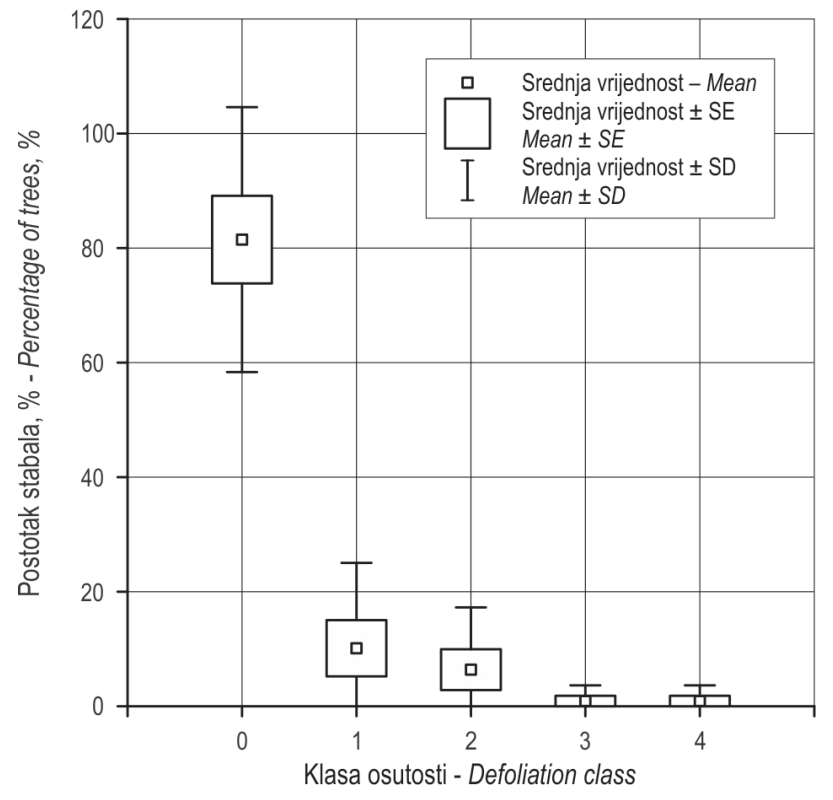

Slika 3. Usporedba postotka stabala obične jele (\%) po stupnjevima osutosti krošanja od 1999. do 2017. godine

Fig. 3 Comparison of the percentage of silver fir trees (\%) by crown defoliation classes for the period 1999-2017

Na slici 3 prikazana je usporedba prosječnoga udjela stabala obične jele (\%) po stupnjevima osutosti krošanja. Najviše stabala u iznosu od $81 \%$ bilo je bez osutosti krošanja te je imalo dakle stupanj 0 (p $=0,000)$. Stupanj 1 imalo je $10 \%$ stabala, stupanj 2 imalo je $7 \%$ stabala, a stupnjeve 3 i 4 po $1 \%$ stabala obične jele. Nisu utvrđene statistički značajne razlike $\mathrm{u}$ postotku stabala među stupnjevima osutosti krošanja 1, 2, 3 i 4 ( $p>0,05)$.

Značajna osutost obične jele u Republici Hrvatskoj visoka je te se od 2001. do 2011. godine kretala od $66,1 \%$ do $88,5 \%$, dok je u Europi od 2006. do 2008. godine iznosila od 23,9\% do 29,7 \% (Potočić i Seletković 2013). U gospodarskim šumama u Republici Hrvatskoj značajna osutost obične jele bila je najveća na području uprava šuma podružnica Ogulin i Delnice $(>70 \%)$, a najmanja na području Gospića $(40 \%)$ i Senja, $25 \%$ (Potočić i Seletković 2011). Prema izvješću o oštećenosti šumskih ekosustava Republike Hrvatske za 2018. godinu (Potočić 
i dr. 2019) značajna osutost obične jele najniža je u posljednjih deset godina i iznosila je $50 \%$. U 2019. godini značajna osutost krošanja obične jele povećala se i iznosila je 59 \% (Potočić i dr. 2020). Prema rezultatima monitoringa značajna osutost stabala obične jele na bioindikacijskoj plohi u Nacionalnom parku Plitvička jezera ispod je značajne osutosti te vrste u Republici Hrvatskoj, ali i u Europi.

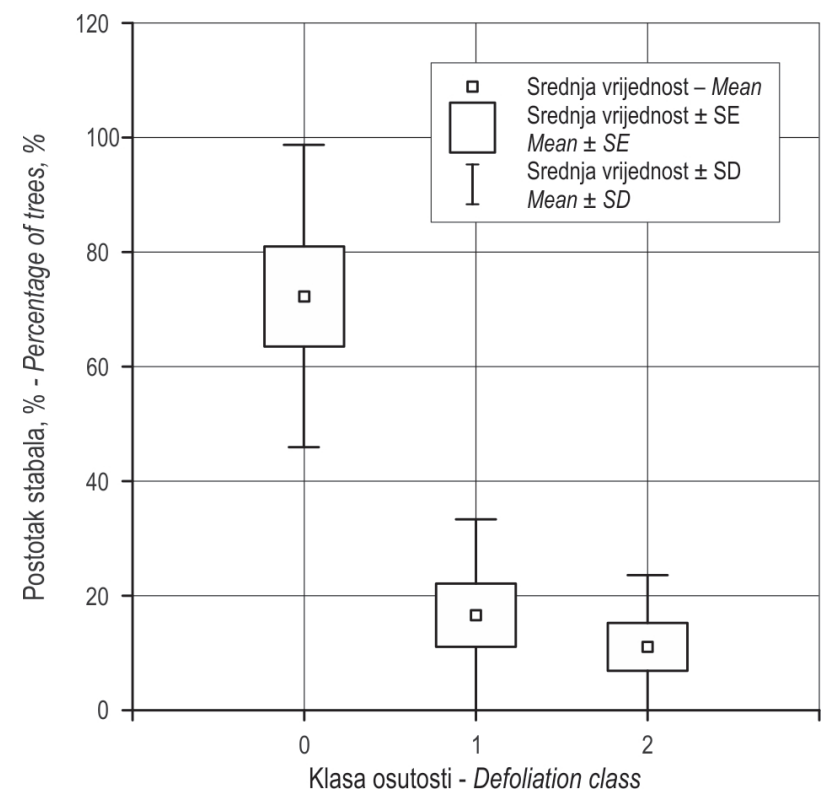

Slika 4. Usporedba postotka stabala obične smreke (\%) po stupnju osutosti krošanja od 1999. do 2017. godine

Fig. 4 Comparison of the percentage of common spruce trees (\%) by crown defoliation classes for the period 1999-2017

Na slici 4 prikazana je usporedba postotka stabala obične smreke po stupnjevima osutosti krošanja. Najviše stabala prosječno $\mathrm{u}$ iznosu od $72 \%$ bilo je bez osutosti krošanja te je imalo dakle stupanj 0 (p $=0,000$ ). Osutost 1 . stupnja imalo je prosječno $17 \%$ stabala, a 2. stupnja prosječno $11 \%$ stabala obične smreke. Nisu utvrđene statistički značajne razlike u postotku broja stabala obične smreke između stupnja 1 i 2 ( $p>0,05)$.

Zbog relativno maloga udjela $u$ drvnom obujmu u šumama u Hrvatskoj na nacionalnoj razini ne postoje podaci o osutosti krošanja obične smreke. Međutim, uprave šuma podružnice Delnice za područje Gorskoga kotara i Gospić za područje Like u sklopu svojih odjela za ekologiju prate stanje krošanja stabala glavnih vrsta šumskoga drveća, pa tako i obične smreke. Prema podacima tih dviju podružnica na pojedinim lokalitetima u gospodarskim šumama pojačano odumiru stabla obične smreke.
U 2010. godini u Gorskom je kotaru bilo 3,56 \% zdravih stabala, $14,92 \%$ slabo osutih, $71,92 \%$ srednje osutih, 9,36\% jako osutih i 0,24 \% mrtvih stabala obične smreke (Čavlović 2010). Prema Matiću (2011) obična je smreka ugroženija u Gorskom kotaru u odnosu na dio areala u Lici. Postotak stabala obične smreke s osutim krošnjama u Hrvatskoj iznosi $59 \%$, i to u sastojinama koje se nalaze u najvišim debljinskim razredima, što upućuje na njihovu visoku dob (Matić 2011). U Nacionalnom parku Plitvička jezera stanje sa smrekom zbog napada potkornjaka na pojedinim lokalitetima iznimno je loše, mjestimično i katastrofalno. To svakako ovisi i o strukturi takvih sastojina. Naime, prema Matiću (2011) $80 \%$ drvnoga obujma obične smreke u Hrvatskoj nalazi se u najvišim debljinskim razredima, što upućuje na vrlo visoku dob smrekovih šuma u Hrvatskoj, njihovu fiziološku slabost i izloženosti propadanju.

Obična je bukva jedna od najzastupljenijih vrsta šumskoga drveća u Nacionalnom parku, no nje nema na bioindikacijskoj plohi. Međutim, ta je vrsta šumskoga drveća najvitalnija vrsta u Hrvatskoj $\mathrm{s}$ relativno malom značajnom osutosti krošanja. U razdoblju od 2009. do 2019. godine značajna osutost krošanja stabala obične bukve ima tendenciju blaga rasta, s manje od $10 \%$ u 2009. godini do ispod $20 \%$ u 2019. godini (Potočić i dr. 2020).

Tablica 2. Spearmanov koeficijent korelacije udjela stabala po stupnjevima osutosti krošanja

Table 2 Spearman correlation of tree proportion by crown defoliation classes

\begin{tabular}{|l|c|c|c|c|c|c|}
\hline $\begin{array}{l}\text { Vrsta/stupanj } \\
\text { Species/class }\end{array}$ & $\begin{array}{c}\text { Jela, } \\
\text { ST 0 } \\
\text { Fir } \\
\text { CL 0 }\end{array}$ & $\begin{array}{c}\text { Jela, } \\
\text { ST 1 } \\
\text { Fir } \\
\text { CL 1 }\end{array}$ & $\begin{array}{c}\text { Jela, } \\
\text { ST 2 } \\
\text { Fir } \\
\text { CL 2 }\end{array}$ & $\begin{array}{c}\text { Smreka, } \\
\text { ST 0 } \\
\text { Spruce } \\
\text { CL 0 }\end{array}$ & $\begin{array}{c}\text { Smreka, } \\
\text { ST 1 } \\
\text { Spruce } \\
\text { CL 1 }\end{array}$ & $\begin{array}{c}\text { Smreka, } \\
\text { ST 2 } \\
\text { Spruce } \\
\text { CL 2 }\end{array}$ \\
\hline $\begin{array}{l}\text { Jela, ST 0 } \\
\text { Fir CL 0 }\end{array}$ & 1,00 & - & - & - & - & - \\
\hline $\begin{array}{l}\text { Jela, ST 1 } \\
\text { Fir CL 1 }\end{array}$ & $-0,86^{1}$ & 1,00 & - & - & - & - \\
\hline $\begin{array}{l}\text { Jela, ST 2 } \\
\text { Fir CL 2 }\end{array}$ & $-0,60$ & 0,36 & 1,00 & - & - & - \\
\hline $\begin{array}{l}\text { Smreka, ST 0 } \\
\text { Spruce CL 0 }\end{array}$ & $0,93^{1}$ & $-0,92^{1}$ & $-0,56$ & 1,00 & - & - \\
\hline $\begin{array}{l}\text { Smreka, ST 1 } \\
\text { Spruce CL 1 }\end{array}$ & $-0,83^{1}$ & $0,911^{1}$ & 0,53 & $-0,94{ }^{1}$ & 1,00 & - \\
\hline $\begin{array}{l}\text { Smreka, ST 2 } \\
\text { Spruce CL 2 }\end{array}$ & $-0,94^{1}$ & $0,78^{1}$ & $0,69^{1}$ & $-0,88^{1}$ & $0,74^{1}$ & 1,00 \\
\hline
\end{tabular}

${ }^{1}$ Signifikantno na razini $p<0,05-$ Significant at $p<0.05$

U tablici 2 prikazan je Spearmanov koeficijent korelacije udjela stabala obične jele i obične smreke po stupnjevima osutosti krošanja. Uočavamo pozitivnu korelaciju za te dvije vrste šumskoga drveća 
po istim stupnjevima osutosti krošanja stabala. Povećanjem postotka stabala obične jele prema stupnju osutosti 0 povećavao se i postotak stabala obične smreke prema stupnju osutosti 0. Ista zakonitost vrijedi i za stupanj osutosti 1 i 2, što znači da su obična jela i obična smreka jednako reagirale na neke okolišne čimbenike koji utječu na osutost krošanja te da imaju neka ekološka obilježja ista ili slična. Utvrđena je negativna korelacija za različite stupnjeve osutosti krošanja po vrstama drveća, što znači da se povećanjem postotka broja stabala u stupnju osutosti 0 smanjuje postotak broja stabala u stupnju osutosti 1 i 2.

Logističkom regresijom analizirali smo utjecaj suše na pojavu stabala obične jele i obične smreke sa značajnom osutosti krošanja, odnosno osutosti krošanja većom od $25 \%$. Prema rezultatima suša nije imala značajan utjecaj na pojavu stabala obične jele sa značajnom osutosti krošanja $(p=0,764$, Chi2(1) = 0,09001), dok je suša imala značajan utjecaj na pojavu takvih stabala kod obične smreke ( $\mathrm{p}=0,045$, Chi2(1) $=3,9895)$. Iz ove analize izlazi da je obična smreka osjetljivija na sušu od obične jele. Razloge tomu treba tražiti u činjenicama da obična smreka ima plitak korijenski sustav (Lakušić 1989) koji je posebno osjetljiv na ekološku sušu odnosno sušu vanjske sredine. Osim toga smreka se na ovim prostorima nalazi na južnoj granici svoga prirodnoga areala, dakle izvan optimuma, te je i manje vitalna na nižoj nadmorskoj visini. Srednja godišnja temperatura zraka u staništu obične smreke kreće se između 4 i 8 ${ }^{\circ} \mathrm{C}$ (Lakušić 1989), dok je na području meteorološke postaje Plitvička jezera srednja godišnja temperatura zraka $9,2{ }^{\circ} \mathrm{C}$. Obična je jela vrsta uske ekološke valencije s obzirom na zahtjeve prema vodi i toplini, ali je i vrsta koje se od sve crnogorice zakorjenjuje najdublje te od rane mladosti stvara biogrupe. Fiziološko srašćivanje korijenja obične jele ima veliko značenje u međuvrsnoj kompeticiji i u opskrbi članova takvih grupa vodom biogenim elementima i asimilatima (Prpić i Seletković 2001). To su činjenice koje idu u prilog boljoj otpornosti obične jele prema suši u odnosu na običnu smreku. Jedno od obilježja suše jest dugotrajni izostanak oborine, a istraživanja Potočića i dr. (2008) otkrivaju relativno mali utjecaj količine oborine na osutost krošanja obične jele i obične bukve. Strana istraživanja s područja Pirineja pokazuju da je obična jela osjetljiva na sušu i da je malen prirast stabala tijekom sušnih razdoblja (Macias i dr. 2006). Prema našim rezultatima s bioindikacijske plohe u Nacionalnom parku Plitvička jezera obična je smreka osjetljiva na sušu, a prema istraživanjima Rötzera i dr. (2017) obična je smreka osjetljivija na sušu u odnosu na običnu bukvu.
Obična je bukva ipak vrsta široke ekološke valencije (Seletković i dr. 2003) i zato bolje podnosi uvjetno rečeno aridnije uvjete $u$ staništu $u$ odnosu na običnu smreku. Ipak, suša je jedan od čimbenika koji utječe na osutost krošanja stabala i obične jele, te obične smreke i obične bukve (Webster i dr. 1996). Stoga je prednost trajnoga monitoringa u dobivanju vremenskoga niza podataka koji omogućuje ispravnije zaključivanje o stanju pojava u ekosustavu (Potočić i Seletković 2011).

\section{Zaključci-Conclusions}

Prema rezultatima praćenja i motrenja osutosti krošanja stabla obične jele i obične smreke dobre su vitalnosti. Tijekom godina monitoringa mrtvih stabala obične jele bilo je samo $8 \%$, dok kod obične smreke nisu zabilježena mrtva stabala ni stabla $\mathrm{s}$ velikom osutosti krošanja. Budući da su na bioindikacijskoj plohi uglavnom stabla prvoga i drugoga debljinskoga razreda, značajna osutost stabala obične jele na bioindikacijskoj plohi ispod je značajne osutosti te vrste u Republici Hrvatskoj, ali i u Europi. Suša nije imala utjecaj na pojavu stabala sa značajnom osutosti krošanja, dok je imala utjecaj na pojavu takvih stabala kod obične smreke. S obzirom na to da je šuma jedan od temeljnih fenomena Nacionalnoga parka Plitvička jezera, potrebno je nastaviti s daljnjim praćenjem stanja krošanja stabala, povećati broj stalnih ploha u samom parku, ali istodobno nastaviti i s monitoringom klime i ostalih ekoloških čimbenika u Nacionalnom parku. Sustavnim praćenjem i motrenjem stanja ekoloških čimbenika i šumskih ekosustava pridonosimo stabilnosti i očuvanju šumskih ekosustava, tj. utvrđivanju uzroka i promjena u tim ekosustavima te osiguranju povoljnih uvjeta za njihov rast i razvoj.

\section{Literatura - References}

Alley, W. M., 1984: The Palmer Drought Severity Index: limitations and assumptions. Journal of Climate and Applied Meteorology 23(7): 1100-1109. https://doi.org/10.1175/1520-0450(1984)023<1100:TPDSIL >2.0.CO;2

Čavlović, J., 2010: Prva nacionalna inventura šuma Republike Hrvatske. Ministarstvo regionalnog razvoja, šumarstva i vodnog gospodarstva, Zagreb, 1-300.

Dobbertin, M., P. Brang, 2001: Crown defoliation improves tree mortality models. Forest Ecology and Management, 141(3): 271-284. https://doi.org/10.1016/S03781127(00)00335-2

Eichhorn, J., P. Roskams, M. Ferretti, V. Mues, A. Szepesi, D. Durrant, I. Seletković, H-W. Schröck, S. Nevalainen, F. Bussotti, P. Garcia, S. Wulff, 2016: Part IV: Visual as- 
sessment of crown condition and damaging agents. In: UNECE ICP Forests Programme Coordinating Centre (ed.): Manual on methods and criteria for harmonized sampling, assessment, monitoring and analysis of the effects of air pollution on forests. Thünen Institute of Forest Ecosystems, Germany, 54 p.

Gruber, F., 1994: Morphology of coniferous trees: Possible effects of soil acidification on the morphology of Norway spruce and silver fir. In: D. Godbold, A. Hüttermann (eds.): Effects of Acid Rain on Forest Processes. New York: Wiley-Liss, 265-324.

Lakušić, R., 1989: Ekologija biljaka. SOUR »Svjetlost«, Sarajevo, 1-248.

Macias, M., L. Andreu, O. Bosch, J. J. Camarero, E. Gutierrez, 2006: Increasing aridity is enhancing silver fir (Abies alba Mill.) water stress in its south-western distribution limit. Climatic Change, 79: 289-313. https://doi. org/10.1007/s10584-006-9071-0

Matić, S., 2011: Utjecaj stanišnih promjena i načina gospodarenja na sušenje obične smreke (Picea abies Karst) u Hrvatskoj. Croatian Journal of Forest Engineering, 32(1): 7-17.

Michel, A., W. Seidling, A. K. Prescher (eds.), 2018: Forest Condition in Europe: 2018 Technical Report of ICP Forests. Report under the UNECE Convention on Long-range Transboundary Air Pollution (Air Convention). BFW-Dokumentation 25/2018. Vienna: BFW Austrian Researche Centre for Forests, $92 \mathrm{p}$.

NN 54/2019: Pravilnik o načinu motrenja oštećenosti šumskih ekosustava. Narodne novine, 54/2019, Zagreb.

Prpić, B., Z. Seletković, 2001: Ekološka konstitucija obične jele. U: B. Prpić (ur.): Obična jela (Abies alba Mill.) u Hrvatskoj. Akademija šumarskih znanosti i Hrvatske šume p.o. Zagreb, Zagreb, 255-276.

Potočić, N., I. Seletković, D. Ugarković, A. Jazbec, S. Mikac, 2008: The influence of climate properties on crown condition of Common beech (Fagus sylvatica L.) and Silver fir (Abies alba Mill.) on Velebit. Periodicum biologorum, 110(2): 145-150.

Potočić, N., I. Seletković, 2011: Osutost šumskog drveća u Hrvatskoj u razdoblju od 2006. do 2009. godine. Šumarski list, 13: 149-158.

Potočić, N., I. Seletković, 2013: Osutost šumskog drveća u Hrvatskoj u razdoblju od 2001. do 2011. godine. Radovi, 45(2): 211-223, Hrvatski šumarski institut.

Potočić, N., I. Seletković, T. Jakovljević, H. Marjanović, K. Indir, J. Medak, M. Anić, M. Ognjenović, N. Zorić, 2019:
Oštećenost šumskih ekosustava Republike Hrvatske, Izvješće za 2018. godinu. Hrvatski šumarski institut, ICP Forests HR, 82 str.

Potočić, N., I. Seletković, T. Jakovljević, H. Marjanović, K. Indir, J. Medak, M. Ognjenović, N. Zorić, 2020: Oštećenost šumskih ekosustava Republike Hrvatske, Izvješće za 2019. godinu. Hrvatski šumarski institut, ICP Forests HR, 91 str.

Rötzer, T., K. H. Häberle, C. Kallenbach, R. Matyssek, G. Schütze, H. Pretzch, 2017: Tree species and size drive water consumption of beech/spruce forests - a simulation study highlighting growth under water limitation. Plaint and Soil, 418: 337-356. https://doi.org/10.1007/s11104-0173306-x

Seletković, Z., I. Tikvić, B. Prpić, 2003: Ekološka konstitucija obične bukve. U: S. Matić (ur.): Obična bukva u Hrvatskoj. Akademija šumarskih znanosti, Hrvatske šume d.o.o. Zagreb, Grad Zagreb, Gradski ured za poljoprivredu i šumarstvo, Zagreb, 155-163.

Spellerberg, I. F., 2005: Monitoring Ecological Change. Cambridge University Press, 391 p. https://doi. org/10.1017/CBO9780511614699

TIBCO Software Inc., 2018: Statistica (data analysis software system), version 13. http://tibco.com.

Tikvić, I., D. Ugarković, J. Gašpar, 2011: Prostorna analiza odumiranja stabala hrasta lužnjaka (Quercus robur L.) za potrebe adaptivnog gospodarenja šumskim ekosustavima u Hrvatskoj. Croatian Journal of Forest Engineering, 32(1): 43-56.

Ugarković, D., I. Tikvić, Z. Seletković, 2011: Odnos stanišnih i strukturnih čimbenika prema odumiranju i ishrani stabala obične jele (Abies alba Mill.) u Gorskom kotaru. Croatian Journal of Forest Engineering, 32(1): 57-71.

UNECE ICP Forests Programme Co-ordinating Centre (ed.), 2016: Manual on methods and criteria for harmonized sampling, assesment, monitoring and analysis of the effects of air pollution on forests. Thünen Institute of Forest Ecosystems, Eberswalde.

Webster, R., A. Rigling, L. Walthert, 1996: An analysis of crown condition of Picea, Fagus and Abies in relation to environment in Switzerland. Forestry, 69(4): 347-355. https://doi.org/10.1093/forestry/69.4.347

Wells, N., S. Goddard, M. J. Hayes, 2004: A Self-Calibrating Palmer Drought Severity Index. Journal of Climate 17(12): 2335-2351. https://doi.org/10.1175/1520-0442(2004) 017<2335:ASPDSI $>2.0 . C O ; 2$ 


\section{Abstract}

\section{Vitality of Forest Trees on Bioindication Plot in Plitvice Lakes National Park}

Defoliation of trees is one of the indicators of the vitality of forest trees. The aim of the study was to analyse the crown defoliation of silver fir and common spruce trees from the bioindication plot in the Plitvice Lakes National Park. From the Level 1 Register of the National Forest Ecosystem Damage Monitoring Program, data were collected on the defoliation of silver fir and common spruce trees from the bioindication plot in the Plitvice Lakes National Park. Values of the self-calibrated Palmer Dryness Index (scPDSI) were collected from the KNMI Climate Explorer web application. Given the crown defoliation and the mortality of trees, common fir and spruce are of good vitality on the bioindication plot. Drought had a significant impact on moderate to severe defoliation of common spruce trees, while this was not the case with silver fir. It is necessary to continue monitoring the vitality of forest trees and increase the number of plots by monitoring the crown defoliation of trees, climate and other environmental factors in the area of the national park.

Keywords: crown defoliation, silver fir, common spruce, Plitvice Lakes National Park

Primljeno (Received): 10. 7. 2020.

Prihvaćeno (Accepted): 27. 8. 2020.
Adrese autorâ - Authors' addresses:

Izv. prof. dr. sc. Damir Ugarković* e-pošta: dugarkovic@sumfak.unizg.hr Prof. dr. sc. Ivica Tikvić e-pošta: ivica.tikvic@zg.htnet.hr Šumarski fakultet Sveučilišta u Zagrebu Zavod za ekologiju i uzgajanje šuma Svetošimunska cesta 25 10000 Zagreb HRVATSKA

Ana Hodak, univ. bacc. ing. silv. e-pošta: hodak.ana99@gmail.com Čatrnja 113 47245 Rakovica HRVATSKA

Krešimir Popić, mag. ing. silv. e-pošta: kresimir.popic@hrsume.hr Hrvatske šume d.o.o. Uprava šuma podružnica Vinkovci Šumarija Lipovac Matije Gupca 5 32246 Lipovac HRVATSKA

* Glavni autor - Corresponding author 
